\title{
KONSEP PEMBELAJARAN BAHASA ARAB DENGAN PENDEKATAN KOMUNIKATIF DI KELAS VII SMP MUHAMMADIYAH 1 DEPOK
}

\author{
Rika Lutfiana Utami ${ }^{1}$ \\ Universitas Islam Negeri Sunan Kalijaga \\ E-mail: rika.lutfiana11@gmail.com \\ DOI: $10.24252 / \mathrm{saa} . v 8 \mathrm{i1.12270}$
}

\begin{abstract}
Abstrak
Belajar bahasa merupakan pembelajaran yang tidak mudah, khususnya bahasa asing. Di antara bahasa asing yang dipelajari peserta didik di sekolah adalah bahasa Arab dan di masyarakat khususnya umat Islam bahasa Arab dianggap sebagai bahasa dalam agama. Pembelajaran bahasa Arab di sekolah membutuhkan tujuan, strategi, teknik, metode, dan pendekatan yang sesuai. Dalam penelitian ini mengkaji pendekatan komunikatif yang digunakan dalam pembelajaran bahasa Arab. Tujuan dari pembelajaran bahasa Arab dengan pendekatan komunikatif adalah agar peserta didik lebih aktif dalam belajar bahasa Arab, mampu berkomunikasi dengan menggunakan bahasa Arab yang dipelajari di dalam kelas. Dalam penelitian ini metode yang digunakan adalah penelitian lapangan dengan menggunakan pendekatan deskriptif kualitatif. Pembelajaran bahasa Arab dengan pendekatan komunikatif juga memperhatikan karakteristik peserta didik yang mana mereka berada pada masa peralihan dari sekolah dasar (SD/MI) ke sekolah menengah (SMP/MTs).
\end{abstract}

Kata Kunci: Pembelajaran Bahasa Arab, Pendekatan Komunikatif.

\section{PENDAHULUAN}

Pendidikan di Indonesia saat ini sedang dihadapkan kepada situasi yang kurang menguntungkan. Minimalnya ada dua masalah utama yang dihadapi dunia pendidikan Indonesia saat ini. Masalah pertama berkenaan dengan rendahnya mutu pendidikan. Masalah ini berhubungan erat dengan perkembangan kebutuhan masyarakat atas hasil pendidikan yang berkualitas. Hal ini sejalan dengan perkembangan tuntutan dunia kerja yang tidak hanya membutuhkan lulusan yang berorientasi unt uk kebutuhan dunia industri. Lulusan yang dibutuhkan saat ini adalah lulusan yang memiliki kompetensi unggul terutama dalam hal kemampuan berpikir. Dengan demikian kebutuhan lulusan saat ini adalah lulusan yang berorientasi kepada kerja pikiran.

Masalah kedua adalah masalah yang bertemali dengan karakter dan budaya bangsa. Masalah ini muncul ditandai dengan berbagai fenomena kehidupan masyarakat Indonesia yang menunjukkan semakin lemahnya karakter dan budaya bangsa yang selama ini diyakini telah mengakar dengan kuat. Bertemali dengan pendidikan, runtuhya mentalitas anak bangsa yang dapat disaksikan sekarang ini diyakini sebagai akibat dari pola pendidikan yang mengabaikan pengembangan karakter dan budaya bangsa. ${ }^{1}$

Mengajar bukanlah persoalan yang mudah, bukan semata persoalan menceritakan, mentransfer informasi atau pengetahuan dari guru ke siswa. Begitu juga dengan belajar,

${ }^{1}$ Yunus Abidin, Pembelajaran Bahasa Berbasis Pendidikan Karakter, (Bandung: PT Refika Aditama, 2012), hal.vii 
bukanlah konsekwensi otomatis dari penuangan informasi ke dalam benak pikiran siswa. Belajar memerlukan keterlibatan mental dan kerja siswa sendiri. Penjelasan dan pemeragaan dalam penyampaian informasi belum tentu membuahkan hasil belajar yang maksimal. Hasil belajar hanya akan diingat dan dirasakan manfaatnya oleh siswa bila ia ikut aktif terlibat.

Belajar bahasa merupakan usaha yang tidak gampang dan kadang menjenuhkan, bahkan kadang kala membuat orang frustasi. Hal itu disebabkan karena belajar bahasa merupakan upaya untuk membangun situasi dan kondisi baru dalam diri seseorang untuk dapat berinteraksi dan berkomunikasi dengan pemilik bahasa tersebut. Kondisi baru tersebut adakalanya berbeda sama sekali dengan kondisi bahasa ibu, baik dalam tataran sistem fonologi, marfologi, maupun sintaksisnya, dan ada kalanya memiliki kemiripan dengan kondisi bahasa ibunya. ${ }^{2}$

Pendidikan bahasa Arab di Indonesia telah mengalami perkembangan yang pesat. Pada mulanya bahasa Arab datang berbarengan dengan masuknya agama Islam di Indonesia. Dalam perkembangannya hingga kini pendidikan bahasa Arab telah disentuh oleh berbagai tingkatan pendidikan dari pendidikan dasar hingga pendidikan tinggi di Indonesia. ${ }^{3}$

Dalam pembelajaran bahasa ada tiga istilah yang perlu dipahami pengertian dan konsepnya secara tepat, yakni pendekatan, metode dan teknik. Edward M. Anthony dalam artikelnya "Approach, Method and Tehnique" sebagaimana dikutip oleh Rodhiyah Zainuddin menjelaskan ketiga istilah tersebut sebagai berikut:

1. Pendekatan (Approach), yang dalam bahasa Arab disebut madkhal adalah; seperangkat asumsi berkenaan dengan hakikat belajar mengajar bahasa. Pendekatan bersifat aksiomatis atau filosofis yang berorientasi pada pendirian, filsafat, dan keyakinan yaitu sesuatu yang diyakini tetapi tidak mesti dapat dibuktikan.

2. Metode (method) yang dalam bahasa Arab disebut thariqah adalah rencana menyeluruh yang berkenaan dengan penyajian materi bahasa secara teratur atau sistematis berdasarkan pendekatan yang ditentukan.

3. Sedangkan Teknik (tehnique), yang dalam bahasa Arab disebut uslub atau yang populer dalam bahasa kita dengan strategi, yaitu kegiatan spesifik yang diimplementasikan di dalam kelas, selaras dengan pendekatan dan metode yang telah dipilih.

Dari paparan di atas dapat dipahami, bahwa ketiga istilah tersebut memiliki hubungan yang hirarkis. Dari satu pendekatan bisa menghadirkan satu aau beberapa metode, dan dari satu metode bisa mengimplementasikan satu atau beberapa strategi. Sebaliknya strategi harus konsisten dengan metode dan karena itu tidak boleh bertentangan dengan pendekatan. Meskipun penggunaan istilah ini terkesan tumpang tindih namun tidak perlu dirisaukan, karena masing-masing punya sejarah dan konteksya sendiri-sendiri. ${ }^{4}$

Walaupun dianggap sebagai bahasa asing oleh bangsa Indonesia, bahasa Arab tidak asing di telinga mereka, terutama umat Islam. Sayangnya, sebagaian besar mereka masih beranggapan bahwa bahasa Arab hanyalah bahasa agama sehingga perkembangannya terbatas di lingkungan kaum muslimin yang memperdalam ilmu-ilmu agama. Hanya lingkunga kecil saja yang menyadari betapa bahasa Arab merupakan bahasa multidimensi

2 Umi Mahmudah \& Abdul Wahab Rosyidi, Active Learning Dalam Pembelajaran Bahasa Arab, (Malang: UIN Maliki Press, 2008), hal. III-IV

${ }^{3}$ Maksudin \& Qoim Nurani, Pengembangan Kurikulum Pembelajaran Bahasa Arab Teori Dan Praktik, (Yogyakarta: Pascasarjana FITK UIN Sunan Kalijaga, 2018), hal. 7

4 Abd Wahab Rosyidi \& Mamlu'atul Ni'mah, Memahami Konsep Dasar Pembelajaran Bahasa Arab, (Malang: UIN Maliki Press, 2012), hal. 33 
yang digunakan oleh para cendikiawan dalam memproduksi karya-karya besar di berbagai bidang disiplin ilmu seperti sejarah, filsafat, matematika, fisika, sastra, dan lain-lain. ${ }^{5}$

Pembelajaran bahasa asing melibatkan sekurang-kurangnya tiga disiplin ilmu, yakni (a) linguistik, (b) psiklogi, dan (c) ilmu pendidikan. Linguistik memberi informasi kepada kita mengenai bahasa secara umum dan mengenai bahasa-bahasa tertentu. Psikologi menguraikan bagaimana orang belajar sesuatu, dan Ilmu Pendidikan atau Pedagogi memungkinkan kita untuk meramu semua keterangan dari (a) dan (b) menjadi satu cara atau metode yang sesuai untuk dipakai di kelas untuk memudahkan proses pembelajaran bahasa oleh pelajar. ${ }^{6}$

Pendekatan (madkhal, approach) tidak dapat dipisahkan dari pembelajaran bahasa, sebab pendekatan merupakan landasan filosofis yang menjadi pintu gerbang bagi perumusan kegiatan pembelajaran. Pendekatan merupakan sesuatu yang bersifat filosofis dan aksiomatis yang tidak dapat dibantah kebenarannya. Pendekatan merupakan dasar dan latar belakang filosofis mengenai materi atau pokok bahasa yang hendak diajarkan. Dengan kata lain pendekatan merupakan asumsi yang mendasari pembelajaran bahasa dan asumsi dasar kita tentang bahasa dan psikologi belajar. ${ }^{7}$

Dari hasil observasi yang telah dilakukan, dalam proses pembelajaran di kelas VII SMP Muhammadiyah 1 Depok secara umum yaitu guru mengajar menggunakan buku ajar bahasa Arab, menerjemahkan teks, serta mencari mufradat yang belum diketahui oleh peserta didik didalam buku pelajaran bahasa Arab. Dari hasil observasi yang telah dilakukan, peneliti menemukan beberapa masalah yang terdapat di sana, diantaranya para peserta didik bukan dari lulusan sekolah madrasah (MI), peserta didik sering lupa dengan pelajaran bahasa Arab yang telah dipelajari, kurangnya minat dalam belajar bahasa Arab, dan kurangnya jam pelajaran bahasa Arab. Oleh karena itu, dari masalah-masalah tersebut, peneliti membuat judul "Konsep Pengembangan Pembelajaran Bahasa Arab Dengan Pendekatan Komunikatif Di Kelas VII SMP Muhammadiyah 1 Depok".

Tujuan dari penelitian ini dilakukan adalah untuk mengetahui bagaimana pembelajaran bahasa Arab pada peserta didik kelas VII di SMP Muhammadiyah 1 Depok, dan untuk mengetahui bagaimana pendekatan komunikatif diterapkan dalam pembejaran bahasa Arab, serta untuk menemukan dan mendeskripsikan kesulitan peserta didik dalam belajar bahasa Arab.

\section{METODE PENELITIAN}

Penelitian ini merupakan penelitian lapangan dengan pendekatan deskriptif kualitatif. Data yang dikumpulkan berupa kata-kata maupun informasi lainnya yang didapat dari wawancara dengan guru bahasa Arab di SMP Muhammadiyah 1 Depok yang beralamat di Maguwoharjo, Depok, Sleman, Yogyakarta, dan penelitian ini bukan penelitian yang berupa angka. Dalam hal ini, penelitian kualitatif merupakan metode penelitian yang dikumpulkan umumnya berupa kata-kata (tertulis maupun lisan) dan perbuatan-perbuatan manusia, tanpa ada upaya untuk mengangkakan data yang telah diperoleh. ${ }^{8}$

${ }^{5}$ Acep Hermawan, Metodologi Pembelajaran Bahasa Arab, (Bandung: PT Remaja Rosdakarya, 2011), hal. 1

${ }^{6}$ Acep Hermawan, Metodologi Pembelajaran Bahasa Arab, hal. 33 hal. 266

${ }^{7}$ Maksudin \& Qoim Nurani, Pengembangan Kurikulum Pembelajaran Bahasa Arab Teori Dan Praktik,

${ }^{8}$ Afrizal, Metode Penelitian Kualitatif Sebuah Upaya Mendukung Penggunaan Penelitian Kualitatif Dalam Berbagai Disiplin Ilmu, (Jakarta: PT Raja Grafindo Persada, 2015), hal. 17 


\section{LANDASAN TEORI}

\section{Pembelajaran Bahasa Arab}

Stigma yang berkembang di masyarakat menunjukkan bahwa belajar bahasa Arab masih dianggap sulit dan rumit, padahal setiap bahasa memiliki tingkatan kesulitan dan kemudahan yang berbeda-beda tergantung pada karakteristik sistem bahasa itu sendiri, baik sistem fonologi, morfologi, maupun sintaksis dan semantiknya. ${ }^{9}$

Pembelajaran yang diidentikkan dengan kata "mengajar" berasal dari kata dasar "ajar" yang berarti petunjuk yang diberikan kepada orang supaya diketahui (diturut) ditambah dengan awalan "pe" dan akhiran "an menjadi "pembelajaran", yang berarti proses, perbuatan, cara mengajar atau mengajarkan sehingga anak didik mau belajar.

Dengan kata lain, kegiatan pembelajaran adalah kegiatan yang di dalamnya terdapat proses mengajar, membimbing, melatih, memberi contoh, dan atau mengatur serta memfasilitasi berbagai hal kepada peserta didik agar bisa belajar sehingga tercapai tujuan pendidikan. Pembelajaran juga diartikan sebagai usaha sistematis yang memungkinkan terciptanya pendidikan. Pembelajaran adalah proses interaksi peserta didik dengan pendidik dan sumber belajar pada suatu lingkungan belajar. Pembelajaran merupakan bantuan yang diberikan pendidik agar dapat terjadi proses pemerolehan ilmu dan pengetahuan, penguasaan kemahiran dan tabiat, serta pembentukan sikap dan kepercayaan kepada peserta didik. Dengan kata lain, pembelajaran adalah proses untuk membantu peserta didik agar dapat belajar dengan baik. ${ }^{10}$

Adapun menurut Oemar Hamalik, pembelajaran adalah suatu kombinasi yang tersusun meliputi unsur-unsur manusiawi, material, fasilitas, perlengkapan dan prosedur yang saling mempengaruhi utuk mencapai tujuan pembelajaran, dalam hal ini manusia terlibat dalam sistem pengajaran terdiri dari siswa, guru dan tenaga lainnya, materi meliputi; buku-buku, papan tulis, dan lain-lainnya. Fasilitas dan perlengkapan terdiri dari ruang kelas dan audiovisual. Prosedur meliputi jadwal dan metode penyampaian informasi, praktek belajar, ujian dan sebagainya. ${ }^{11}$

Pembelajaran bahasa Arab meliputi: (a) tujuan, (b) pendekatan, (c) metode, (d) teknik, serta (e) strategi. Kelima unsur tersebut saling berhubungan dan berkaitan satu sama lain agar tercapai pembelajaran bahasa Arab yang optimal, sesuai dengan yang diharapkan. Kelima unsur dalam pembelajaran bahasa Arab adalah sebagai berikut:

\section{Tujuan Pembelajaran Bahasa Arab}

Tujuan pembelajaran bahasa Arab menjadi bagian integral dengan tujuan pendidikan nasional, tujuan institusional, tujuan kurikuler mata pelajaran. Karena itu, tujuan pembelajaran bahasa Arab sesuai dan memperkuat serta dalam rangka mencapai tujuan pendidikan nasional, tujuan institusional, dan tujuan kurikuler mata pelajaran. Secara teoritis, terdapat beberapa tujuan pendidikan bahasa Arab, di antaranya yang disebutkan oleh Fathul Mujib adalah:

a. Tujuan religius

Orientasi ini mengedepankan bahwa belajar bahasa Arab memiliki tujuan untuk memahami dan memahamkan Islam. Dalam memahami ajaran agama Islam tentu harus

\footnotetext{
${ }^{9}$ Syaiful Mustofa, Strategi Pembelajaran Bahasa Arab Inovatif, (Malang: UIN Maliki Press, 2011), hal. 1

${ }^{10}$ M. Khalilullah, Media Pembelajaran Bahasa Arab, (Yogyakarta: Aswaja Presindo), hal. 3

${ }^{11}$ M. Khalilullah, Media Pembelajaran Bahasa Arab, hal. 4
} 
memahami teks-teks pengetahuan ajaran agama Islam. Oleh karena itu orientasi ini lebih condong mengajarkan bahasa Arab sebagai alat untuk dapat membaca (fahm al-maqru') teksteks kajian ajaran Islam. ${ }^{12}$

b. Tujuan akademik

Pendidikan bahasa Arab dipandang dengan tujuan untuk memahami keterampilan berbahasa Arab menurut orientasi tersebut. Di antara keterampilan tersebut adalah mendengar (istima'), berbicara (kalam), membaca (qira'ah), dan menulis (kitabah). Bahasa Arab ditempatkan sebagai sebuah objek kajian pengetahuan yang harus dikuasai secara akademik.

c. Tujuan profesional

Bahasa Arab telah banyak digunakan oleh banyak kalangan menyebabkan terdapat orientasi yang mendasari bahwa belajar bahasa Arab merupakan tuntutan agar dapat memenuhi kebutuhan praktis. Artinya tidak harus belajar secara akademik dapat menguasai bahasa Arab yang akan diaplikasikan secara praktis sesuai dengan kepentingan yang dimaksud.

d. Tujuan ideologis dan ekonomis

Selain orientasi yang telah disebutkan sebelumnya, belajar bahasa Arab juga telah dilakukan untuk kepentingan perang misalnya ataupun kepentingan pengembangan perekonomian. Pembelajaran ini memiliki tujuan agar dapat menguasai dan memahami kebudayaan sasaran.

Tujuan pembelajaran bahasa Arab di Indonesia yang dilakukan pada lembaga-lembaga pendidikan dapat dikatakan masih setengah-setengah di antara tujuan akademik (keilmuan) dan tujuan kemahiran. Yaitu dengan adanya tuntutan untuk menguasai kemahiran berbahasa serta dituntut untuk mampu menerjemahkan dan mempelajari bahasa Arab dari segi linguistiknya. Hal ini menjadikan pembelajaran bahasa Arab mengalami disorientasi. ${ }^{13}$

e. Tujuan pembelajaran lebih otentik dan kontekstual

Tujuan pembelajaran bahasa Arab di kelas harus lebih otentik dan bermakna. Artinya para siswa ditekankan dan diarahkan untuk mempelajari dan menggunakan bahasa bukan hanya sebatas bahasa yang jauh dari jangkauan siswa, melainkan lebih dekat dengan perilaku keseharian siswa misalnya. Setiap kegiatan yang dilakukan bermakna bagi siswa dan lebih kontekstual. Tujuan ini sangat penting untuk dipertimbangkan dalam pembelajaran selain tujuan utama adalah untuk mempelajari dan menggunakan bahasa sebagai alat komunikasi baik lisan maupun tulisan.

f. Tujuan diarahkan pada penggunaan bahasa sasaran

Berkomunikasi dengan bahasa sasaran (bahasa Arab) merupakan tujuan yang dikedepankan dalam pembelajaran bahasa Arab pendekatan komunikatif. Bahasa sasaran/tujuan menjadi kunci pada suksesnya pembelajaran dengan pendekatan komunikatif, karena dengan minimnya penggunaan bahasa pertama dan maksimalisasipenggunaan bahasa sasaran, kompetensi komunikatif yang otentik akan tercipta dengan optimal. Dalam situasi pembelajaran, bahasa Arab digunakan sebagai bahasa komunikasi, tidak hanya sebagai pengetahuan melainkan juga sebagai bahasa yang dipakai (use). ${ }^{14}$

\footnotetext{
${ }^{12}$ Maksudin \& Qoim Nurani, Pengembangan Kurikulum Pembelajaran Bahasa Arab Teori Dan Praktik, hal. 7

${ }^{13}$ Maksudin \& Qoim Nurani, Pengembangan Kurikulum Pembelajaran Bahasa Arab Teori Dan Praktik, hal. 8

${ }^{14}$ Maksudin \& Qoim Nurani, Pengembangan Kurikulum Pembelajaran Bahasa Arab Teori Dan Praktik, hal. 9
} 


\section{Pendekatan Pembelajaran Bahasa Arab}

Pendekatan (Approach), yang dalam bahasa Arab disebut madkhal adalah; seperangkat asumsi berkenaan dengan hakikat belajar mengajar bahasa. Pendekatan bersifat aksiomatis atau filosofis yang berorientasi pada pendirian, filsafat, dan keyakinan yaitu sesuatu yang diyakini tetapi tidak mesti dapat dibuktikan. Misalnya saja asumsi dari aural-oral approach yang menyatakan bahwa bahasa adalah apa yang kita dengar dan ucapkan, sedangkan tulisan hanyalah representasi dari ujaran. Dari asumsi ini dapat dijewantahkan dalam hubungannya dengan pembelajaran dan belajar bahasa, bahwa keterampilan menyimak dan berbicara harus dibelajarkan terlebih dahulu sebelum keterampilan membaca dan menulis. ${ }^{15}$

Dalam pembelajaran/pengajaran bahasa Arab dikenal lima macam pendekatan, yaitu:

a. Pendekatan kemanusiaan (Humanistic Approach)

Pendekatan kemanusiaan yang dalam bahasa Arab disebut dengan al-madkhal alinsani. Pendekatan ini sangat memfokuskan kepada peserta didik. Peserta didik dipandang sebagai manusia yang harus diperlakukan secara manusiawi, bukan alat atau benda mati yang menerima rangsangan-rangsangan dan meresponnya. ${ }^{16}$

b. Pendekatan berbasis media (Media Based Approach)

Pendekatan berbasis media yang dalam bahasa Arab disebut al-madkhal al-tiqoni, adalah pendekatan yang mengandalkan kepada teknik penggunaan media pengajaran. Sebagaimana diketahui bahwa sarana atau alat peraga (alat bantu) besar peranannya dalam menyampaikan keahlian dan mengubahnya dari keahlian abstrak kepada keahlian yang kongkrit. Pendekatan ini bertujuan untuk melengkapi konteks yang menjelaskan makna katakata, struktur dan istilah-istilah kebudayaan baru melalui gambar, peta, foto, contoh model yang hidup, kartu dan segala sesuatu yang membantu menjelaskan makna kata asing kepada murid.

\section{c. Pendekatan aural-oral (Aural-Oral Approach)}

Pendekatan aural-oral yang dalam bahasa Arab disebut al-madkhal al-sama'i alsyafahi. Pendekatan ini memiliki asumsi, bahwa bahasa adalah apa yang didengar dan yang diucapkan, sedangkan tulisan hanyalah representasi dari ujaran. Berangkat dari asumsi ini, maka bahasa yang pertama adalah ujaran. Asumsi ini diperkuat dengan adanya faktor kebiasaan, karena suatu perilaku akan menjadi kebiasaan apabila diulang berkali-kali itu, begitupula dengan pengajaran bahasa, harus dilakukan dengan teknik pengulangan atau repetisi.

\section{Approach)}

d. Pendekatan analisis dan non- analisis (Analytical and Non Analytical

Pendekatan analisis dan non-analisis yang dalam bahasa Arab disebut al-madkhal altahlili wa ghair al-tahlili, adalah pendekatan yang digagas oleh Stem dalam kongres tahun 70-an. Pendekatan analisis adalah pendekatan yang menjadikan sosio-linguistik sebagai dasar pertimbangan analisis. Pendekatan non- analisis adalah pendekatan yang menjadikan pembahasan psycho-linguistik dan ilmu pendidikan sebagai asas pertimbangan analisis yang bersifat global, integral dan alami.

e. Pendekatan komunikatif (Communicative Approach)

Pendekatan komunikatif yang dalam bahasa Arab disebut al-madkhal al-ittishali, adalah pendekatan yang memfokuskan kepada kemampuan komunikasi aktif dan praktis.

\footnotetext{
15 Abd Wahab Rosyidi \& Mamlu'atul Ni'mah, Memahami Konsep Dasar Pembelajaran Bahasa Arab, hal. 33

${ }^{16}$ Abd Wahab Rosyidi \& Mamlu'atul Ni’mah, Memahami Konsep Dasar Pembelajaran Bahasa Arab, hal. 35
} 
Pendekatan komunkatif ini, merupakan pendekatan yang akan dibahas oleh peneliti dalam pembahasan dibawah.

\section{f. Pendekatan pembelajaran aktual}

Dari perubahan proses pembelajaran yang berpusat pada guru menuju pembelajaran yang berpusat pada siswa melahirkan berbagai pendekatan pembelajaran yang bertujuan untuk membelajarkan siswa. Di antaranya adalah; Pendekatan Konstruktivisme, Pendekatan Kontekstual, Quantum Pembelajaran dan Pengajaran, Pembelajaran Kooperatif, dan PAKEM atau PAIKEM. ${ }^{17}$

\section{Metode Pembelajaran Bahasa Arab}

Metode (method) yang dalam bahasa Arab disebut thariqah adalah rencana menyeluruh yang berkenaan dengan penyajian materi bahasa secara teratur atau sistematis berdasarkan pendekatan yang ditentukan. Jika pendekatan bersifat aksiomatis, maka metode bersifat prosedural. Sehingga dalam satu pendekatan bisa saja terdapat beberapa metode.

Setiap metode memiliki segi-segi kekuatan dan kelemahannya masing-masing. Sebuah metode seringkali lahir karena ketidakpuasannya terhadap metode sebelumnya, tetapi pada waktu yang sama, metode yang baru secara bergiliran juga terjebak dalam kelemahan yang dahulu menjadi penyebab lahirnya metode yang dikritiknya itu. Metode pengajaran dikelompokkan menjadi tiga, yaitu 1) metode yang berpusat pada bahasa, 2) metode yang berpusat pada pembelajaran, dan 3 ) metode yang berpusat pada siswa. ${ }^{18}$

\section{Teknik Pembelajaran Bahasa Arab}

Teknik (tehnique), yang dalam bahasa Arab disebut uslub atau yang populer dalam bahasa kita dengan strategi, yaitu kegiatan spesifik yang diimplementasikan di dalam kelas, selaras dengan pendekatan dan metode yang telah dipilih. Teknik bersifat operasional, karena itu sangatlah tergantung pada imajinasi dan kreativitas seorang pengajar dalam meramu materi dan mengatasi dan memecahkan berbagai persoalan di kelas. Teknik pembelajaran biasanya tercermin dalam rencana pelaksanaa pembelajaran (RPP) yang dibuat oleh guru, khususnya pada bagaian langkah-langkah pembelajaran. ${ }^{19}$

\section{Strategi Pembelajaran Bahasa Arab}

Kata "strategi" berasal dari kata yunani "strategia" yang berarti ilmu perang atau panglima perang. Berdasarkan pengertia ini, maka strategi adalah suatu seni merancang suatu operasi di dalam peperangan, seperti cara-cara mengatur posisi atau siasat berperang angkatan darat amaupun angkatan laut. Secara umum sering diungkapkan strategi sebagai suatu teknik yang digunakan untuk mencapai suatu tujuan.

Menurut Kamus Besar Bahasa Indonesia strategi adalah ilmu dan seni menggunakan semua sumber daya bangsa-bangsa untuk melaksanakan kebijaksanaan tertentu dalam perang dan damai. Sedangkan strategi pembelajaran atau bisa disebut dengan teknik pengajaran

\footnotetext{
hal. 39

${ }^{18}$ Abd Wahab Rosyidi \& Mamlu'atul Ni'mah, Memahami Konsep Dasar Pembelajaran Bahasa Arab, hal. 48

19 Abd Wahab Rosyidi \& Mamlu'atul Ni’mah, Memahami Konsep Dasar Pembelajaran Bahasa Arab, hal. 69
}

${ }^{17}$ Abd Wahab Rosyidi \& Mamlu'atul Ni'mah, Memahami Konsep Dasar Pembelajaran Bahasa Arab, 
adalah operasionalisasi dari metode. Strategi menurut Gagne berarti proses pembelajaran yang menyebabkan peserta didik berpikir untuk memecahkan masalah dalam mengambil keputusan. ${ }^{20}$

\section{Pendekatan Komunikatif}

Awal mula munculnya pendekatan komunikatif ini dilatari oleh ketidak puasannya terhadap penggunaan metode audio-lingual, yang meski telah berjalan sejak tahun enam puluhan, tetapi tidak kunjung memberikan perubahan berupa kemampuan berkomunikasi secara lancar. Teori yang dijadikan landasan pun sering dikecam oleh para linguis karena suatu pendekatan aural-oral atau metode audio-lingual didasarkan atas teori tata bahasa strukturalisme dan teori ilmu jiwa behaviorisme.

Noam Choamsky, seorang pencetus teori tata bahasa transformasi-generatif dari Amerika Serikat sangat mengecam linguistik struktural karena teori ini tidak mampu menunjukkan hubungan-hubungan yang berkaitan dengan makna, dan tidak mampu menunjukkan hubungan antar kalimat. Sebenarnya, setiap manusia memiliki kemampuan belajar bahasa yang dibawa sejak lahir, yang biasa disebut dengan jihaz iktisab al-lughah atau Language Acquisition Devic (LAD).

Kritikan yang disampaikan Choamsky ini akhirnya mendorong para ahli dan praktisi pengajaran bahasa untuk melakukan evaluasi terhadap konsep-konsep pembelajaran bahasa yang berlaku selama ini. Oleh karena itu, bersamaan dengan lahirnya teori kognitivisme dalam psikologi, teori transformasi-generatif dalam linguistik, dan teori LAD dalam psikolinguistik, maka muncullah berbagai pendekatan dan metode baru dalam pengajaran bahasa. $^{21}$

Pendekatan berasal dari bahasa Inggris yaitu approach yang memiliki arti pendekatan. Di dalam dunia pengajaran, approach atau pendekatan dapat diartikan cara memulai pembelajaran. Menurut pendapat Wahjoedi, pendekatan pembelajaran adalah cara mengelola kegiatan belajar dan perilaku siswa agar ia dapat aktif melakukan tugas belajar sehingga dapat memperoleh hasil belajar secara optimal.

Pendekatan komunikatif yang dalam bahasa Arab disebut al-madkhal al-ittisha:li, adalah pendekatan yang memfokuskan kepada kemampuan komunikasi aktif dan praktis. Menurut para pemerhati bahasa, pendekatan ini telah melakukan terobosan baru yang strategis di bidang pembelajaran bahasa kedua, dan dianggap sebagai pendekatan yang integral dan memiliki ciri-ciri yang pasti. Hal ini karena pendekatan tersebut merupakan perpaduan strategi-strategi yang bertumpu pada satu tujuan tertentu yang pasti, yaitu melatih murid menggunakan bahasa secara langsung (spontanitas) dan kreatif, di samping penguasaan tata bahasa. Dengan demikian prinsip-prinsip pendekatan ini mendorong murid untuk berani menggunakan bahasa Arab. Sasaran pendekatan ini adalah memberikan kesempatan kepada peserta didik untuk berani menggunakan bahasa Arab pada situasi yang alami dengan sikap spontanitas kreatif, di samping penguasaan tata bahasa. Sedang fokusnya adalah menyampaikan makna atau maksud yang tepat, sesuai dengan tuntutan dan fungsi komunikasi pada waktu itu. Sedangkan tata bahasa dalam perspektif pendekatan ini hanyalah sekedar pengetahuan akan makna kalimat dan jabatan kata-katanya, sehingga

${ }^{20}$ Syaiful Mustofa, Strategi Pembelajaran Bahasa Arab Inovatif, hal. 8

${ }^{21}$ Subur, Pendekatan Dan Strategi Pembelajaran Bahasa Arab, (Insania: Jurnal Pemikiran Alternatif Kependidikan, Vol. 11, No. 2, 2006), hal. 2 
peserta didik diharapkan dapat mengungkapkan pikiran, perasaan, kemauan dan kayakinan berlandaskan pada kaidah tata bahasa yang tepat. ${ }^{22}$

Pendekatan komunikatif merupakan pendekatan yang dilandasi oleh pemikiran bahwa kemampuan menggunakan bahasa dalam berkomunikasi merupakan tujuan yang harus dicapai dalam pembelajaran bahasa. Tampak bahwa bahasa tidaak hanya dipandang sebagai seperangkat kaidah, tetapi lebih luas lagi, yakni sarana berkomunikasi. Ini berarti, bahasa ditempatkan sesuai dengan fungsinya, yakni fungsi komunikasi. Pendekatan komunikatif adalah suatu pendekatan yang bertujuan untuk meningkatkan keterampilan siswa dalam berkomunikasi, menekankan pembinaan dan pengembangan kemampuan komunikatif siswa. Penerapan pendekatan komunikatif sepenuhnya dilakukan oleh siswa (student centre) sedangkan guru hanya sebagai fasilitator.

Pada dasarnya, pendekatan komunikatif adalah pendekatan pembelajaran bahasa yang lebih menekankan pembelajaran pada penguasaan kecakapan berbahasa daripada penguasaan struktur bahasa. Kompetensi komunikatif merupakan kemampuan untuk menerapkan kaidah gramatikal suatu bahasa dalam membentuk kalimat yang benar dan untuk mengetahui kapan, dimana, dan kepada siapa kalimat itu diujarkan. Dengan berbekal kompetensi komunikatif, seseorang dapat menyampaikan dan menginterpretasikan suatu pesan atau menegosiasikan makna secara interpersoal dalam konteks yang lebih spesifik. Krashen juga menegaskan bahwa kompetensi komunikatif lebih menekankan fungsi bahasa dalam komunikasi sesungguhnya daripada menguasai bentuk dan kaidah kebahasaan. Kaidah-kaidah kebahasaan itu hanya berfungsi untuk memonitor suatu bentuk ujaran. ${ }^{23}$

\section{Karakteristik Peserta Didik}

Pada umumnya, karakteristik atau ciri khas perkembangan menurut Gleitmen adalah progressive dalam arti tumbuh dan berkemabang semakin maju. Contohnya, perkembagan motor bayi yang semula hanya memiliki kemampuan merangkak berkembang menjadi kemampuan berdiri, kemampuan berjalan dan kemampuan berlari. ${ }^{24}$ Setiap individu dikatakan sebagai peserta didik apabila ia telah memasuki usia sekolah. Usia 4 sampai 6 tahun, di taman kanak-kanak. Usia 6 atau 7 tahun di sekolah dasar. Usia 13-16 tahun di SMP dan usia 16-19 tahun di SLTA. Jadi, peserta didik adalah anak, individu, yang tergolong dan tercatat sebagai siswa di dalam satuan pendidikan. ${ }^{25}$

Setiap individu memiliki ciri, sifat bawaan (heredity), dan karakteristik yang diperoleh dari pengaruh lingkungan sekitarnya. Ahli psikologi berpendapat bahwa kepribadian dibentuk oleh perpaduan faktor pembawaan dan lingkungan. Karakteristik bawaan, baik yang bersifat biologis maupun psikologis, dimiliki sejak lahir. Apa yang dipikirkan, dikerjakan, atau dirasakan seseorang, atau merupakan hasil perpaduan antara apa yang ada di antara faktor-faktor biologis yang diwariskan dan pengaruh lingkungan sekitarnya.

Tanpa memedulikan umur seorang anak, karakteristik pribadi yang dibawa ke sekolah terbentuk dari pengaruh lingkungan. Hal itu berpengaruh cukup besar terhadap keberhasilan atau kegagalannya di sekolah dan pada masa-masa perkembangan selanjutnya. Karakteristik yang berkaitan dengan perkembangan faktor biologis cenderung lebih bersifat tetap (ajeg),

\footnotetext{
${ }^{22}$ Abd Wahab Rosyidi \& Mamlu'atul Ni’mah, Memahami Konsep Dasar Pembelajaran Bahasa Arab, hal. 38

23 Ahmad Muaradi, Pendekatan Komunikatif Dalam Pembelajaran Bahasa Arab, (Arabiyat: Jurnal Pendidikan Bahasa Arab Dan Kebahasaaraban, Vol. 1, No. 1, 2014), hal. 32-33

${ }^{24}$ Muhibbin Syah, Telaah Singkat Perkembangan Peserta Didik, (Jakarta: Rajawali Pers), hal. 30

${ }^{25}$ Enung Fatimah, Psikologi Perkembangan Peserta Didik, (Bandung: CV Pustaka Setia, 2008), hal. 12
} 
sedangkan karakteristik yang berkaitan dengan faktor psikologis lebih mudah berubah karena dipengaruhi oleh pengalaman dan lingkungan. ${ }^{26}$

Pada usia sekolah menengah, penampilan siswa berubah sebagai akibat perubahan hormon. Cara hidup mereka berubah sesuai dengan perkembangan kemampuannya untuk mulai berpikir abstrak. Di usia ini, siswa mengalami masa transisi antara masa anak dan masa dewasa. Pada umumnya dimulai pada usia 12 atau 13 tahun dan berakhir menjelang usia 20 tahun. $^{27}$

\section{PEMBAHASAN}

Berdasarkan hasil penelitian yang di lakukan oleh Khodijah dan Mardiah Astuti tentang Pendekatan Komunikatif Terhadap Keterampilan Berbicara Siswa Pelajaran Bahasa Inggris di MIN 1 Palembang, hasil penelitian tersebut sebelum diterapkan pendekatan komunikatif menunjukkan $57 \%$ dari 30 siswa tergolong sedang dalam keterampilan berbicara pelajaran bahasa Inggris. Kemudian setelah diterapkan pendekatan komunikatif terdapat pengaruh yang signifikan sebanyak 5\% pada siswa kelas IVC di MIN 1 Palembang pada keterampilan berbicara pelajaran bahasa Inggris. ${ }^{28}$ Dari penelitian yang dilakukan oleh Khodijah dan Mardiah Astuti, dapat disimpulkan bahwa pendekatan komunikatif memiliki pengaruh yang yang signifikan dalam pembelajaran bahasa khususnya keterampilan berbicara pada pelajaran bahasa Inggris.

Berdasarkan penelitian di atas, pendekatan komunikatif dalam pembelajaran bahasa Arab memiliki pengaruh dan keterkaitan yang erat, dimana pendekatan komunikatif memiliki tujuan agar para peserta didik dalam belajar bahasa Arab memiliki skill dalam berkomunikasi. Dalam pembelajaran bahasa Arab dengan pendekatan komunikatif terdapat beberapa karakteristik pada masa ini diantaranya:
a. Pertumbuhan fisik/ jasmani
b. Perkembangan intelektual
c. Perkembangan emosional
d. Perkembangan sosial, moralitas dan sikap
e. Perkembangan pemikiran politik
f. Perkembangan agama dan keyakinan

\section{KESIMPULAN}

Belajar bahasa merupakan usaha yang tidak gampang dan kadang menjenuhkan, bahkan kadang kala membuat orang frustasi. Pendidikan bahasa Arab di Indonesia telah mengalami perkembangan yang pesat. Dalam pembelajaran bahasa membutuhkan konsep yang secara tepat dapat tercapai tujuan pembelajaran bahasa Arab, meliputi: tujuan, pendekatan, metode, teknik, dan strategi. Kegiatan pembelajaran adalah kegiatan yang di dalamnya terdapat proses mengajar, membimbing, melatih, memberi contoh, dan atau mengatur serta memfasilitasi berbagai hal kepada peserta didik agar bisa belajar sehingga tercapai tujuan pendidikan. Adapun pendekatan (madkhal, approach) tidak dapat dipisahkan dari pembelajaran bahasa, sebab pendekatan merupakan landasan filosofis yang menjadi pintu gerbang bagi perumusan kegiatan pembelajaran. Dan pendekatan komunikatif

\footnotetext{
${ }^{26}$ Enung Fatimah, Psikologi Perkembangan Peserta Didik, hal. 13

${ }^{27}$ Mulyani Sumantri, Perkembangan Peserta Didik, (Banten: Universitas Terbuka, 2014), hal. 3.3-3.8

28 Khodijah \& Mardiah Astuti, Pendekatan Komunikatif Terhadap Keterampilan Berbicara Siswa Pelajaran Bahasa Inggris di MIN 1 Palembang, (JIP: Jurnal Ilmiah PGMI, Vol.3, 2017), hal. 153
} 
merupakan pendekatan yang dilandasi oleh pemikiran bahwa kemampuan menggunakan bahasa dalam berkomunikasi merupakan tujuan yang harus dicapai dalam pembelajaran bahasa. Dengan berbekal kompetensi komunikatif, seseorang dapat menyampaikan dan menginterpretasikan suatu pesan atau menegosiasikan makna secara interpersoal dalam konteks yang lebih spesifik.

\section{DAFTAR PUSTAKA}

Abidin, Y. (2012). Pembelajaran Bahasa Berbasis Pendidikan Karakter. Bandung: PT Refika Aditama.

Afrizal. (2015). Metode Penelitian Kualitatif Sebuah Upaya Mendukung Penggunaan Penelitian Kualitatif Dalam Berbagai Disiplin Ilmu. Jakarta: PT Rajagrafindo Persada.

Fatimah, E. (2008). Psikologi Perkembangan Peserta Didik. Bandung: CV Pustaka Setia.

Hermawan, A. (2011). Metodologi Pembelajaran Bahasa Arab. Bandung: PT Remaja Rosdakarya.

Khalilullah, M. (t.t.). Media Pembelajaran Bahasa Arab. Yogyakarta: Aswaja Presindo.

Khodijah \& Mardiah Astuti. 2017. Pendekatan Komunikatif Terhadap Keterampilan Berbicara Siswa Pelajaran Bahasa Inggris di MIN 1 Palembang. JIP: Jurnal Ilmiah PGMI. Vol.3.

Mahmudah, U., \& Wahab Rosyidi, A. (2008). Active Learning Dalam Pembelajaran Bahasa Arab. Malang: UIN Maliki Press.

Maksudin, \& Nurani, Q. (2018). Pengembangan Kurikulum Pembelajaran Bahasa Arab Teori Dan Praktik. Yogyakarta: Pascasarjana FITK UIN Sunan Kalijaga.

Muradi, A. (2014). Pendekatan Komunikatif Dalam Pembelajaran Bahasa Arab. Arabiyat: Jurnal Pendidikan Bahasa Arab Dan Kebahasaaraban, 1(1), 29-48. https://doi.org/10.15408/a.v1i1.1129

Mustofa, S. (2011). Strategi Pembelajaran Bahasa Arab Inovatif. Malang: UIN Maliki Press.

Subur, S. (2006). Pendekatan dan Strategi Pembelajaran Bahasa Arab. INSANIA : Jurnal Pemikiran Alternatif Kependidikan, 11(2), 164-175. https://doi.org/10.24090/insania.v11i2.165

Sumantri, M. (2014). Perkembangan Peserta Didik. Banten: Universitas Terbuka.

Syah, M. (t.t.). Telaah Singkat Perkembangan Peserta Didik. Jakarta: Rajawali Pers.

Wahab Rosyidi, A., \& Ni'mah, M. (2012). Memahami Konsep Dasar Pembelajaran Bahasa Arab. Malang: UIN Maliki Press. 